\title{
Distribution Law of Principal Stress Difference of Deep Surrounding Rock of Gob-side Entry and Optimum Design of Coal Pillar Width
}

\author{
Ji LI, Xubo QIANG, Wenshuo WANG, Fei WANG
}

\begin{abstract}
The optimum design of deep-coal pillar width at the gob-side entry is the key to control surrounding rocks. Existing studies on this issue are based on the distribution law of mining abutment pressure without considering the principal stress difference distribution, which is related to the shear failure of surrounding rock. This study aimed to optimize the design of deep-coal pillar width at gob-side entry based on the distribution law of the principal stress difference. With FLAC 3D numerical simulation, the distribution characteristics of principal stress difference in the side mining stress field of the deep mining face and the distribution laws of the principal stress difference of the surrounding rock at the gob-side entry under different coal pillar width were explored. According to the distribution characteristics of the principal stress difference, the coal and rock mass on the goaf side in the deep mining face could be divided into three zones, i.e., decreasing, increasing and stable zones. Results show that the principal stress differences of the deep surrounding rock on the roof, floor, and coal wall rib at the gob-side entry present a single-peak curve distribution under different coal pillar width. However, the principal stress difference of the surrounding rock on the coal pillar rib displays a single-peak curve when the coal pillar width is less than or equal to 8 $\mathrm{m}$, but a double-peak curve appears when the coal pillar width is greater than $8 \mathrm{~m}$. The peak value of the shallow surrounding rock is obviously smaller than that of the deep surrounding rock. The width of the coal pillar of the gob-side entry in 11030-tunnel was optimized according to the theoretical calculation. This work provides a novel idea and method for the arrangement of deep coal pillars of gob-side entry.
\end{abstract}

Keywords: coal pillar width; deep roadway; gob-side entry; principal stress difference

\section{INTRODUCTION}

As a rich source of fuel, coal is one of the main sources of energy in the human world [1]. Coal mining has been gradually transferred to deep place year by year with increasing mining intensity and depletion of shallow coal resources [2-3]. Driving roadway along next goaf with narrow coal pillar has been adopted for most mining roadways in the deep coal mining face to improve the resource recovery ratio and relieve the pressure in mining and development replacement. The stress field is higher at deep coal and rock mass and the stress environment exhibits particularity at the roadways driving along next goaf compared with those of common mining roadways [4]. As such, the ground pressure behaviour of deep surrounding rock of gob-side entry is serious and violent, leading to difficulty in controlling surrounding rocks. The key point for solving this problem is to design reasonable narrow coal pillar width of gob-side entry to provide a good engineering basis for later control and maintenance of surrounding rocks.

At present, the existing core method of optimizing the coal pillar width of gob-side entry is to arrange the roadways in the side abutment pressure-relaxed area of adjacent faces. This method enables the roadways to be in a favorable stress environment and thus reduces the influence on the stability of the surrounding rock of roadways. Experts and scholars at home and abroad have proposed numerous methods and theories about the optimal design of the coal pillar width of gob-side entry. The main research aspects are as follows: determine the distribution of the side abutment pressure in the mining face through the field measurement of the mining abutment pressure to optimize the coal pillar width design [5-6]; calculate the coal pillar stress distribution under the mining abutment pressure by using elastic-plasticity theory to obtain the width calculation formula of the coal pillar in a stable state and achieve the optimization effect [7-8]; numerical simulation of the distribution characteristics of the mining abutment pressure and the stability of the surrounding rock of roadway under different coal pillar widths by using different computer software to optimize the coal pillar width design [9-10]; and summarize the distribution law of the mining abutment pressure according to the traditional field production experience and optimize the coal pillar width design based on existing experience [11-12]. Therefore, the existing optimum design of the coal pillar width of roadway driving along goaf is based on the distribution law of mining abutment pressure formed in the adjacent mining faces. The abutment pressure mainly represents the change in the vertical stress in the surrounding rock. However, the fracture of coal-rock mass generally follows $\mathrm{M}-\mathrm{C}$ criterion, which is the maximum shear stress. The principal stress difference of the surrounding rock in the stress state determines the occurrence of fracture. The rationality of coal pillar width can be improved by determining its optimum design based on the distribution law of principal stress difference. Therefore, the design of the deep coal pillar width of gobside entry was optimized based on the distribution law of principal stress difference in the surrounding rock of the gob-side entry.

\section{STATE OF THE ART}

Existing research on the optimum design of deep coal pillar width of gob-side entry has focused on analysis of the environmental characteristics of the stress field and the failure mechanism of the surrounding rock of the gob-side entry by numerical simulation and on optimizing the design of coal pillar width. To control the large deformation of deep surrounding rock of the gob-side entry, Yin et al. [13] studied the deformation failure mechanism of the surrounding rock of gob-side entry by various stress fields. Meng Wang [14] studied the vertical stress distribution characteristics of deep coal pillar of gob-side entry by FLAC3D simulation and discussed the instability failure mechanism. Robert Bertuzzi et al. [15] analyzed the 
maximum principal stress distribution law of surrounding rock under different coal pillar widths by numerical simulation according to the data in Africa, the USA, and India; they established a new method for estimating the strength of coal pillar. Jiang L [16] studied the distribution characteristics of side abutment pressure on the deep mining face and the change rule of the vertical stress of surrounding rock of gob-side entry under different coal pillar widths by numerical simulation; this work also proposes the optimum design method of coal pillar width. Ming Z [17] studied the vertical stress distribution of surrounding rock and the deformation characteristics of coal pillar of gob-side entry under different coal pillar widths by numerical simulation; the design of the coal pillar width of gob-side entry was optimized based on the equilibrium theory of coal. V. M. Seryakov et al. [18] conducted research on the mining abutment pressure of the longwall face of fully mechanized mining; they also explored the stress distribution change law of coal and surrounding rock in the roadway driving stage when the roadway is in stagger arrangement. Yuan Zhang [19] studied the distribution law of abutment pressure in deep stope, established a dynamic mechanical model of the roof structure, and finally proposed the optimum design method of coal pillar width of gob-side entry with prevention of large deformation of roof as the core. T. Mallhao et al. [20] studied the evolution law of the vertical stress of coal pillars in four different stages by numerical simulation and established the coal pillar stability prediction model to solve the size design in room pillar mining. Zhang Wei et al. [21] analyzed the distribution characteristics of the advancing abutment pressure of gob-side entry on insular face; they constructed a model of the structural mechanics of surrounding rock of gob-side entry with narrow coal pillar on the insular face. Zheng Xi-gui et al. [22] explored the distribution laws of vertical and horizontal stresses in the entire process of excavation and mining of gob-side entry with different coal pillar widths; they also analyzed the effect of the coal pillar width on the stress evolution of 58 gob-side entry and solid side. Mehdi Najafi et al. [23] established a numerical simulation algorithm to study the vertical stress distribution law of coal pillar along the width direction under the mining abutment pressure of adjacent faces based on different coal pillar widths. Ashok Kumar et al. [24] established a strain-based numerical simulation method, developed correction based on field research and CMRI empirical formula, and studied the vertical stress evolution law of pillars in different mining stages. Mohammad Rezaei [25] constructed the radial basis function neural network (RBFNN), fuzzy inference system (FIS), and statistical analysis (SA) models for predicting the mining stress concentration coefficient (SCC) around the goaf; the results provide a basis for the stability analysis of surrounding pillars and traffic tunnels in long-wall mining. Most of existing studies on the environmental characteristics of stress field of gob-side entry focus only on the vertical or horizontal stresses of surrounding rock but ignore the distribution characteristics of principal stress difference, which is related to the failure of deep coal and rock mass.
To address the limitations of this research field, the present study investigates the distribution laws of principal stress differences in side mining stress field of the deep coal mining face and in surrounding rock of gob-side entry under different coal pillar widths by taking the deep roadway driving along goaf in Zhaogu No. 2 Mine as a typical case. Results are used to optimize the design of the deep coal pillar width of gob-side entry and provide a novel idea and method.

The rest of this study is organized as follows. Chapter 3 elaborates the numerical simulation analysis, theoretical calculation, and field monitoring method used. Chapter 4 analyzes the numerical simulation results, optimizes the design of the coal pillar width of gob-side entry based on the previous analysis and the theoretical calculation, and verifies the optimized coal pillar width in Zhaogu No.2 Mine by field monitoring. Chapter 5 presents the conclusions.

\section{METHODOLOGY}

Experiment was conducted on 11030 transport roadway of Zhaogu No. 2 Mine of Henan Energy and Chemical Group to determine the distribution characteristics of principal stress difference in the side mining stress field of the deep mining face, the distribution law of principal stress difference of surrounding rock of gob-side entry under different coal pillar widths, and the reasonable coal pillar width of gob-side entry. Numerical simulation, theoretical calculation, field test, and other comprehensive methods were conducted.

The main coal seam of Zhaogu No. 2 Mine in Henan Energy and Chemical Group, Henan Province, China, is No. II -1 seam with an average thickness of $6.1 \mathrm{~m}$, an average dip angle of $5^{\circ}$, and a buried depth of about $700 \mathrm{~m}$. The lithology of the coal roof is mainly composed of mudstone, sandy mudstone, and sandstone. The direct roof is about $6.5 \mathrm{~m}$ thick, and the floor is dominated by sandy mudstone and mudstone. The borehole geological histogram is shown in Fig. 1. The mine has decided to carry out transport roadway driving in 11030 face along the goaf of 11011 face, where the mining has been finished (Fig. 2), with a rectangular cross section of $4.8 \mathrm{~m}$ wide $\times 3.3 \mathrm{~m}$ high, to improve the resource recovery rate.

\begin{tabular}{|c|c|c|}
\hline Column & Lithology & Thickness(m) \\
\hline & Sandstone & 5.76 \\
\hline & $\begin{array}{c}\text { Mudstone } \\
\text { Sandy mudstone }\end{array}$ & 6.01 \\
\hline & Coal & 6.48 \\
\hline & Sandy mudstone & 14.27 \\
\hline & L9 Siltstone & 2.00 \\
\hline
\end{tabular}

Figure 1 Geological column 


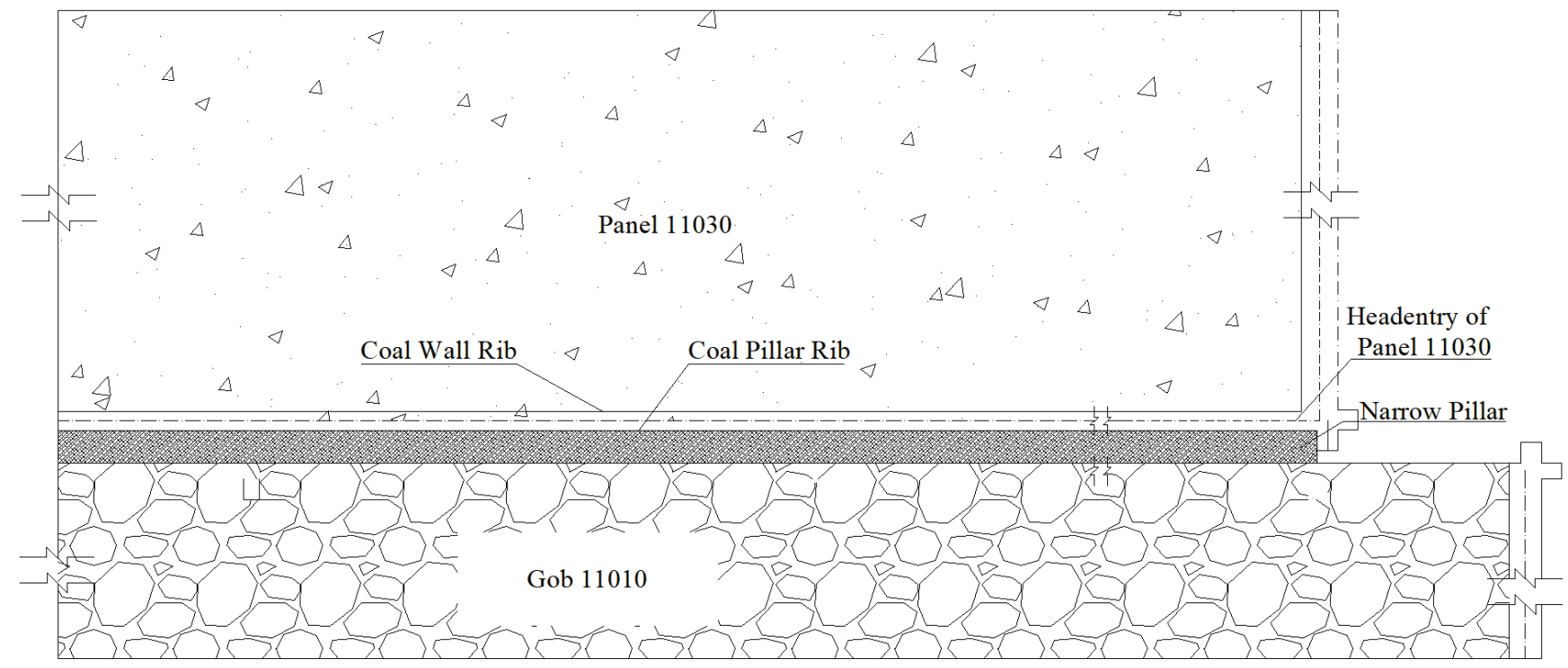

Figure 2 Arrangement plan of carrying roadway along the 11030 working face

\subsection{Numerical Simulation}

The mining stress field distribution on one side of the pillars caused by the mining of adjacent faces will be the basis for the optimum design of deep coal pillar width of gob-side entry because it needs to drive the deep roadway along the goaf of the adjacent faces with narrow coal pillars. In addition, existing research on the distribution of mining stress field focuses on the distribution of abutment pressure, which indicates the change in the vertical stress of surrounding rock. However, the failure of surrounding rock in the stress field environment, where deep roadway is located, is mostly compression-shear failure, which generally conforms to the MC criterion (the maximum shear stress failure criterion) [26]. The principal stress difference of surrounding rock in the stress state determines the occurrence of failure [27-28]. Hereby, the distribution characteristics of principal stress difference in the side mining stress field of the 11011 face and the distribution law of principal stress difference of surrounding rock of gob-side entry under different coal pillar widths were studied by FLAC3D numerical simulation.

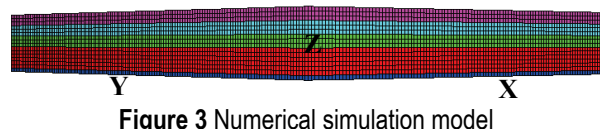

A numerical simulation model was established according to the coal-mine production geological conditions of Zhaogu No. 2 Mine. The FLAC3D numerical simulation model was $250 \mathrm{~m}$ wide $\times 350 \mathrm{~m}$ long $\times 32 \mathrm{~m}$ wide (Fig. 3). The front, side, and rear boundaries of the model were constrained by vertical displacement, and the bottom boundary was constrained by vertical displacement. Vertical stress of $17.5 \mathrm{MPa}$ was applied to the top to simulate the overlying $700 \mathrm{~m}$ strata load. According to the measured data of the ground stress of adjacent mines in the mining area, the stress field was applied to the initial ground by using Ini command: 15.37 $\mathrm{MPa}\left(\sigma_{3}\right)$ of vertical stress and $29.42 \mathrm{Mpa}\left(\sigma_{1}\right)$ and 16.70 $\operatorname{MPa}\left(\sigma_{2}\right)$ of horizontal stress. The constitutive relationship of surrounding rock adopted $\mathrm{MC}$ criterion to the physical and mechanical parameters of each stratum is shown in Tab. 1.

Table 1 Rock mass mechanical properties
\begin{tabular}{|l|c|c|c|c|c|c|}
\hline \multicolumn{1}{|c|}{ Strata } & $\varphi /{ }^{\circ}$ & $C / \mathrm{MPa}$ & $\begin{array}{c}\gamma \\
/ \mathrm{kg} / \mathrm{m}^{3}\end{array}$ & $G / \mathrm{GPa}$ & $K / \mathrm{GPa}$ & $\begin{array}{c}R_{\mathrm{m}} \\
\mathrm{MPa}\end{array}$ \\
\hline Sandstone & 45 & 3.9 & 2700 & 9.0 & 10.2 & 7.5 \\
\hline Sandy mudstone & 35 & 2.4 & 2200 & 6.0 & 7.0 & 1.48 \\
\hline 21 coal & 31 & 1.4 & 1400 & 4.8 & 5.4 & 1.5 \\
\hline Sandy mudstone & 26 & 3.7 & 2400 & 6.5 & 7.6 & 2.6 \\
\hline Siltstone & 35 & 7.9 & 2680 & 5.3 & 8.9 & 8.71 \\
\hline
\end{tabular}

The whole numerical simulation consisted of two parts. In the first part, the excavation of the 11011 face was simulated, and the principal stress difference of coal and rock mass on one side of the goaf was monitored. In the second part, coal pillars with widths of $4,5,6,7,8,9$, and $10 \mathrm{~m}$ were arranged along the 11011 goaf to simulate the excavation of the 11030 transport roadway. The principal stress differences of surrounding rock of different depths on the roof, floor, and middle of coal pillar rib and coal wall rib were monitored.

\subsection{Theoretical Calculation}

When one side of the coal pillar is the mining space and the other side is the preparation roadway, the corresponding plastic zones will be formed on both sides. The inner part of the narrow coal pillar will be the plastic zone with very low stability and bearing capacity. Therefore, the reasonable width of coal pillar should be ensured. After the plastic deformation on both sides of the coal pillar, a certain stable bearing zone is formed to ensure the stable anchorage foundation of the roadway bolt and maintain the stability of the coal pillar. Therefore, the reasonable narrow coal pillar width should meet the following Eq. (1):

$$
X \geq\left(x_{1}+x_{2}\right)
$$

where $X$ is the width of coal pillar (m); $x_{1}$ is the width of the plastic zone produced in the coal body on the side of 
goaf after the mining of adjacent faces (m); and $x_{2}$ is the effective length of bolt (m).

According to limit equilibrium theory [29-30], $x_{1}$ can be calculated by the following Eq. (2):

$x_{1}=\frac{m \lambda}{2 \tan \varphi_{0}} \ln \frac{k \gamma a H+c_{0} / \tan \varphi_{0}}{c_{0} / \tan \varphi_{0}+p_{0} / \lambda}$

where $m$ is the mining height of the coal seam $(\mathrm{m}) ; \lambda$ is the side pressure coefficient; $C_{0}$ is the cohesion of the coal body $(\mathrm{MPa}) ; \varphi_{0}$ is the internal friction angle of the coal body $\left(^{\circ}\right) ; k$ is the stress concentration factor; $H$ is the buried depth of the roadway $(\mathrm{m}) ; \gamma$ is the average volume weight of the rock stratum $\left(\mathrm{MN} / \mathrm{m}^{3}\right)$; and $P_{0}$ is the support strength of the roadway $(\mathrm{MPa})$.

\subsection{Field Monitoring}

The field industrial test was carried out on the coal pillar width of gob-side entry in the 11030 transport tunnel by using the methods in Sections 3.1 and 3.2. The surface displacements of the surrounding rock during gob-side entry were monitored in full section to verify the reasonability of the result after the optimum design. Ten surface displacement monitoring stations were arranged every $10 \mathrm{~m}$, which is the rear of the driving face. Each station arranged the surface displacement monitoring points at the middle of the roof, coal pillar rib, and coal wall rib by the crisscross displacement method, as shown in Fig. 4.

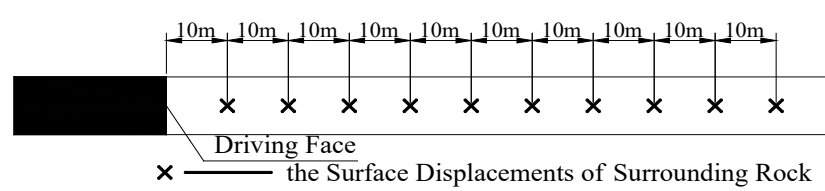

(a)

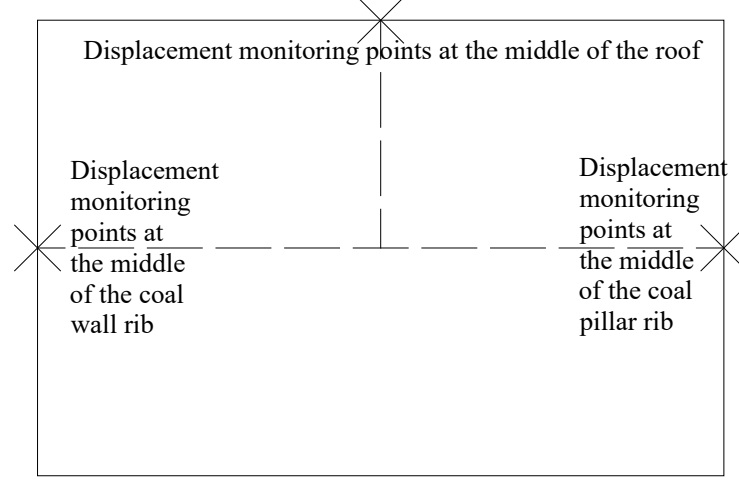

(b)

Figure 4 Field Monitoring Arrangement Diagram: (a) Arrangement of Surface Displacement Monitoring Stations; (b) Arrangement of Surface Displacement Monitoring Points on the Roadway Section

\section{RESULT ANALYSIS AND DISCUSSION \\ 4.1 Environmental Characteristics of Side Mining Stress Field in Deep Mining Face}

Fig. 5 presents the distribution curve of principal stress differences of coal and rock mass on one side of 11011 goaf obtained by using the numerical simulation analysis described in Section 3.1. After mining the 11011 face, the principal stress difference of the side coal and rock mass first increases to the peak and then reduces gradually to a stable value with increasing distance from the edge of the goaf. The principal stress difference of rock surrounding the coal and rock mass within $0-2 \mathrm{~m}$ of the edge of goaf is maintained at a low level due to the surrounding rock fragmentation caused by face mining. With increasing distance from the edge of goaf, the figure rises gradually and reaches the peak at $4 \mathrm{~m}$ away from the edge of goaf. After that, it decreases with increasing distance from the edge of goaf and remains unchanged from $8 \mathrm{~m}$ away from the edge of goaf.

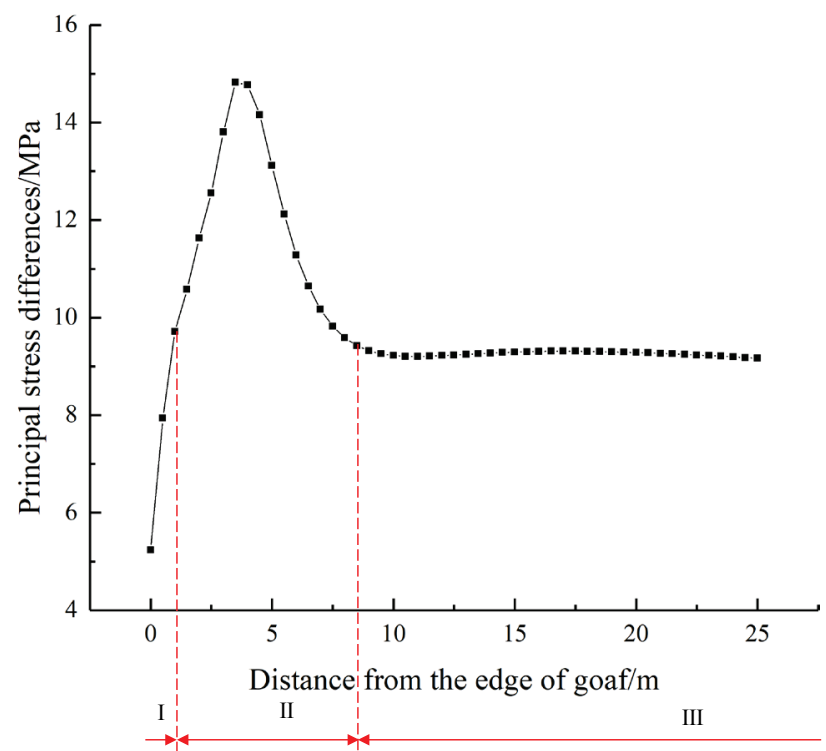

Figure 5 Principal Stress Difference Distribution of Surrounding Rock on the Side of Face: I - Principal Stress Difference Decreasing Zone; II - Principal Stress Difference Increasing Zone; III - Principal Stress Difference Stable Zone

Therefore, the coal and rock mass on the side of goaf can be divided according to the distribution characteristics of the principal stress difference into three zones, namely, decreasing, increasing, and stable zones.

\subsection{Distribution Characteristics of Principal Stress Difference of Deep Surrounding Rock of Gob-side Entry \\ 4.2.1 Distribution Characteristics of Principal Stress Difference}

Fig. 6 presents the distribution law of principal stress difference of surrounding rock of gob-side entry under different coal pillar widths by using the numerical simulation analysis described in Section 3.1. According to the figure:

(1) The distribution laws of principal stress differences on the roof, floor, and coal wall rib are basically the same: it increases rapidly from shallow surrounding rock to the peak and then decreases slowly. The principal stress differences show a sing-peak distribution curve. When the coal pillar width is less than or equal to $8 \mathrm{~m}$, the principal stress difference at the coal pillar rib also shows a singlepeak distribution curve. When it is more than $8 \mathrm{~m}$, the distribution curve of the principal stress difference has two peaks. The peak value of the shallow surrounding rock is obviously smaller than that of the deep surrounding rock. 


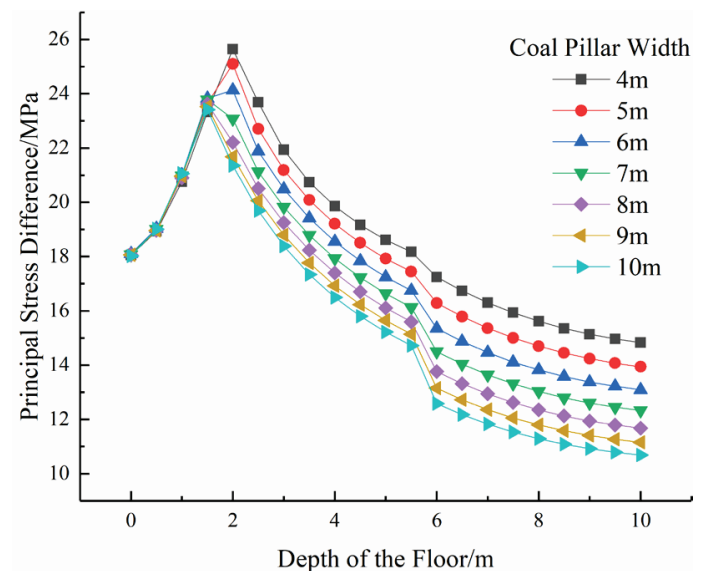

(a)

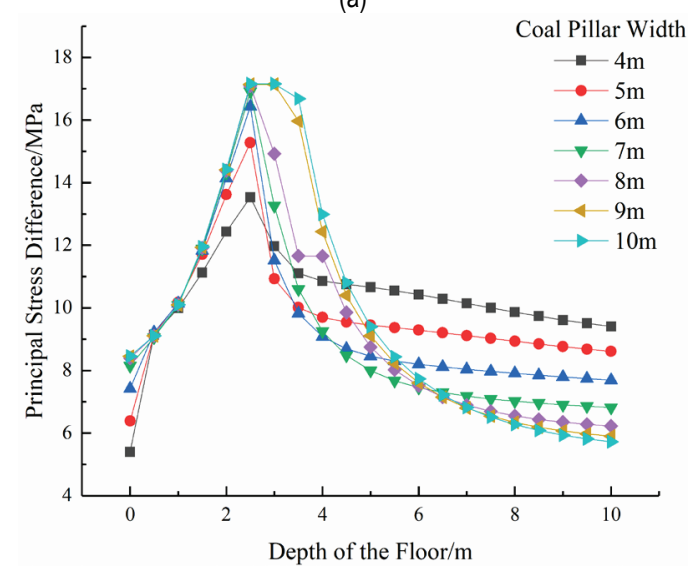

(b)

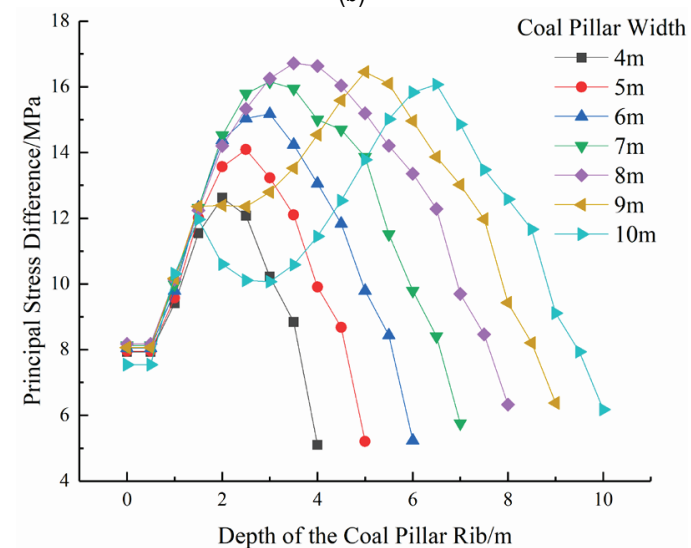

(c)

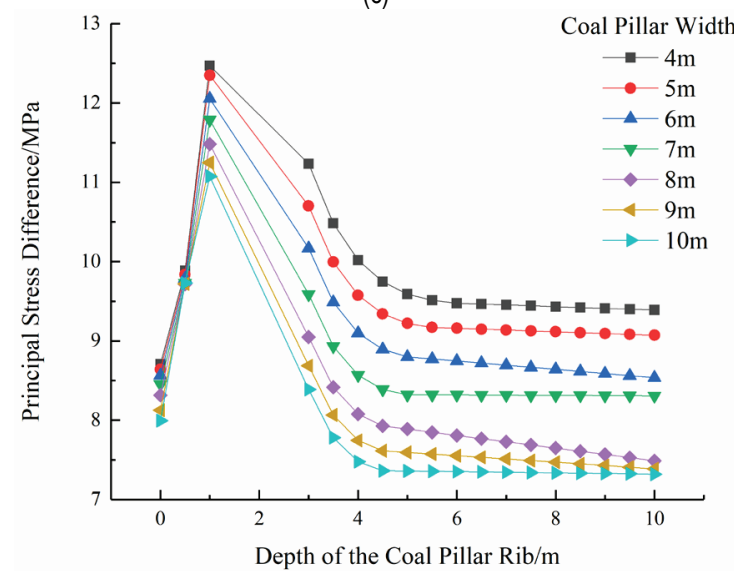

(d)

Figure 6 Distribution Laws of Principal Stress Differences of Surrounding Rock of Gob-side Entry under Different Coal Pillar Widths: (a) Principal Stress

Difference of the Roof; (b) Principal Stress Difference of the Floor; (c) Principal Stress Difference of the Coal Pillar Rib; (d) Principal Stress Difference on the Coal Wall Rib.
(2) Before the peak value, the principal stress differences in the roof and coal wall rib at the same depth of surrounding rock show the same increasing trend. The values are basically the same. After the peak value, at the same depth of the surrounding rock, the smaller the coal pillar width is, the greater the principal stress difference will be.

(3) When the coal pillar width is less than or equal to $8 \mathrm{~m}$, the principal stress difference of surrounding rock of the same depth on the coal pillar rib increases gradually along the same path before reaching the peak value. After the peak value, the bigger the coal pillar width is, the greater the principal stress difference will be. When the coal pillar width is equal to or greater than $8 \mathrm{~m}$, before the peak value, the bigger the coal pillar width is, the smaller the principal stress difference will be. After the peak value, the bigger the coal pillar width is, the greater the principal stress difference will be.

(4) Before the peak value, the principal stress difference of surrounding rock of the same depth on the floor strata gradually increases with increasing coal pillar width. After the peak value, the smaller coal pillar width leads to gentle drop of the principal stress difference. At $6.5 \mathrm{~m}$ high from the floor, the larger the coal pillar width is, the smaller the principal stress difference will be.

\subsubsection{Relationship between the Peak Principal Stress Difference and the Coal Pillar Width}

Fig. 7 shows the curve relationship between the peak principal stress difference of surrounding rock of gob-side entry and the coal pillar width obtained by the numerical simulation analysis described in Section 3.1. According to the figure,

(1) Under the same coal pillar width, the peak principal stress difference of surrounding rock of gob-side entry follows the order: roof $>$ floor $>$ coal pillar rib $>$ coal wall rib.

(2) When the coal pillar width is $4 \mathrm{~m}$, the peak principal stress difference at the roof is the largest. With increasing coal pillar width, it decreases gradually. When the coal pillar width increases to $8 \mathrm{~m}$, the peak principal stress difference remains constant.

(3) With increasing coal pillar width, the peak principal stress difference on the floor increases gradually but the increase amplitude decreases gradually. When the width of the coal pillar increases to $8 \mathrm{~m}$ and continues to increase, the increase in the peak principal stress difference slows down and the peak principal stress difference remains constant.

(4) The distribution curve of the principal stress difference on the coal pillar rib has only one peak. With increasing coal pillar width, the peak principal stress difference increases gradually. When the coal pillar width increases to 8 , the peak principal stress difference reaches the maximum. Thereafter, with the increase of the coal pillar width, the peak principal stress difference decreases gradually.

(5) The peak principal stress difference curve on the coal wall rib basically shows a linear distribution. With the increase of the coal pillar width, the peak principal stress difference decreases gradually. 


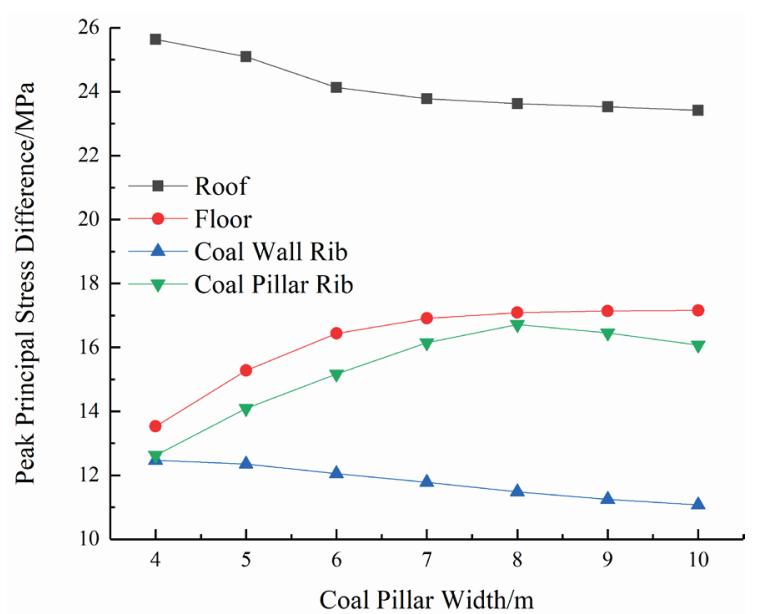

Figure 7 Relationship of the Peak Principal Stress Difference of Surrounding Rock of Gob-side Entry and the Collar Pillar Width

\subsubsection{The Relationship between the Position of the Peak Principal Stress Difference and the Coal Pillar Width}

Fig. 8 presents the relationship curve of the position of the peak principal stress difference of surrounding rock of gob-side entry and the coal pillar width obtained by the numerical simulation analysis described in Section 3.1.

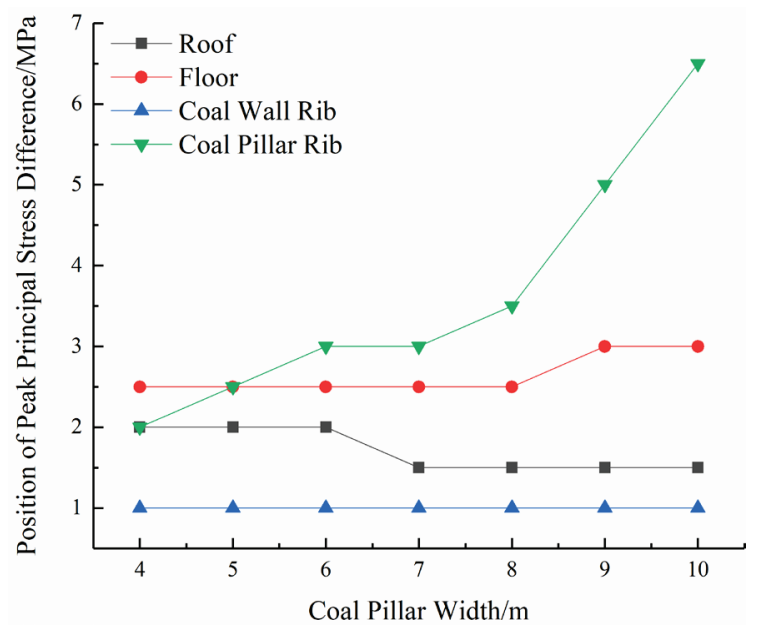

Figure 8 Relationship of the Position of Peak Principal Stress Difference of Surrounding Rock of Gob-side entry and the Coal Pillar Width

According to the figure:

(1) When the coal pillar width is less than or equal to $6 \mathrm{~m}$, the position of the peak principal stress difference on the roof is stabilized at $2 \mathrm{~m}$ deep from the roof. When the coal pillar width increases from $6 \mathrm{~m}$ to $7 \mathrm{~m}$, it shifts to 1.5 $\mathrm{m}$ deep from the roof, a movement of $0.5 \mathrm{~m}$ to the shallow. Then, with the increase of the coal pillar width, the position of the principal stress difference on the roof remains unchanged.

(2) When the coal pillar width is less than or equal to $8 \mathrm{~m}$, the position of the peak principal stress difference on the floor is stabilized at the place $2.5 \mathrm{~m}$ deep from the floor. When the coal pillar width increases from $8 \mathrm{~m}$ to $9 \mathrm{~m}$, it moves to the place $3 \mathrm{~m}$ deep from the roof, a movement of $0.5 \mathrm{~m}$ to the depth. After that, with the increase of the coal pillar width, the position of the principal stress difference on the floor remains unchanged.

(3) When the coal pillar width is less than or equal to $6 \mathrm{~m}$, the peak principal stress difference on the coal pillar rib is located at the center of coal pillar. When the coal pillar width is $7 \mathrm{~m}$ to $8 \mathrm{~m}$, it is no longer located at the center of coal pillar, but deviates towards the place $0.5 \mathrm{~m}$ deviation from the side of roadway (with the center of coal pillar as the base point, the same below). When the coal pillar width is $9 \mathrm{~m}$ to $10 \mathrm{~m}$, it deviates toward the goaf, 1.5 $\mathrm{m}$ away from the coal pillar on the side of goaf.

(4) The position of the peak principal stress difference on the coal wall rib does not change with the increase of the coal pillar width, but maintains unchanged at the surrounding rock $1 \mathrm{~m}$ deep from the coal pillar rib.

It can be drawn from the above analysis that: (1) the principal stress difference on the roof of deep goaf driving roadway shows a single-peak curve distribution. When the coal pillar width is $4 \mathrm{~m}$, the peak principal stress difference $(25.64 \mathrm{MPa})$ on the roof strata and the peak position $(2 \mathrm{~m})$ are the largest. (2) The principal stress difference on the floor also shows a single-peak curve distribution. When the coal pillar width is $10 \mathrm{~m}$, the peak principal stress difference $(17.16 \mathrm{MPa})$ on the roof strata and the peak position $(3 \mathrm{~m})$ are the largest. (3) When the coal pillar width is less than or equal to $8 \mathrm{~m}$, the principal stress difference on the coal pillar rib shows a single-peak curve distribution. When the coal pillar width is greater than $8 \mathrm{~m}$, the principal stress difference shows a double-peak curve distribution. The peak point in the shallow surrounding rock is obviously smaller than that in the deep surrounding rock. When the coal pillar width is $8 \mathrm{~m}$, the peak principal stress difference of surrounding rock on the coal pillar rib is the largest $(16.72 \mathrm{MPa})$. The peak position $(3.5 \mathrm{~m})$ is located within the collar pillar on the side of roadway. (4) The principal stress difference on the coal wall rib also shows a single-peak curve distribution. With increasing coal pillar width, the peak principal stress difference decreases gradually and the peak position remains at the place $1 \mathrm{~m}$ deep from the coal wall rib. When the coal pillar width is $4 \mathrm{~m}$, the peak principal stress difference is the largest (12.47 MPa).

\subsection{Optimum Design of Coal Pillar Width of Deep Gob-side Entry}

An optimum design was carried out on the coal pillar width of gob-side entry in the 11030 face by combining theoretical calculation of narrow coal pillar width based on the distribution characteristics of principal stress difference of surrounding rock of gob-side entry under different coal pillar widths.

\subsubsection{Optimization of the Coal Pillar Width based on Theoretical Calculation}

According to the theoretical calculation in Section 3.2, the values of the parameters in Tab. 2 were substituted into Eq. (2) in Section 3.2 to obtain the width of the plastic zone $\left(x_{1}\right)$ produced in the coal mass on the side of the goaf after mining of adjacent faces $(3.8 \mathrm{~m})$.

Table 2 Values of the Parameters in Eq. (2)

\begin{tabular}{|c|c|c|c|c|c|c|c|c|}
\hline Parameters & $\begin{array}{c}M \\
/ \mathrm{m}\end{array}$ & $\lambda$ & $\begin{array}{c}C_{0} \\
/ \mathrm{MPa}\end{array}$ & $\begin{array}{c}\varphi \\
/\end{array}$ & $k$ & $\begin{array}{c}H \\
/ \mathrm{m}\end{array}$ & $\begin{array}{c}\gamma \\
/ \mathrm{MN} / \mathrm{m}^{3}\end{array}$ & $\begin{array}{c}P_{0} \\
/ \mathrm{MPa}\end{array}$ \\
\hline Values & 3 & 0.52 & 1.4 & 31 & 2.2 & 700 & 0.025 & 0.2 \\
\hline
\end{tabular}


The value of $x_{2}$ is $2.2 \mathrm{~m} . x_{1}$ and $\eta$ were substituted into Eq. (1) in Section 3.2 to obtain:

$X \geq(3.8 \mathrm{~m}+2.2 \mathrm{~m})=6.0 \mathrm{~m}$

Thus, the reasonable narrow coal pillar width obtained by the theoretical calculation method in Section 3.2 should be no less than $6 \mathrm{~m}$.

\subsubsection{Optimization of the Coal Pillar Width based on the Characteristics of the Principal Stress Difference}

From the analysis of the distribution characteristics of the principal stress difference on the side of the goaf in the 11011 face, the coal and rock mass on the side of the goaf in 11011 face can be divided into the principal stress difference decreasing, increasing, and stable zones. Therefore, the design of the coal pillar width should be incorporated to build a roadway located in the principal stress difference decreasing and stable zones rather than the increasing zone. The work also ensured the width of coal pillar as narrow as possible.

According to the distribution characteristics of the principal stress difference on the side of the goaf in 11011 face, when the roadway is located at $2 \mathrm{~m}$ to $8 \mathrm{~m}$ away from the side of the goaf in the 11011 face, the roadway falls in the principal stress difference increasing zone, which will inevitably exert serious influence on the stability of surrounding rock of roadway. When the coal pillar width is less than or equal to $2 \mathrm{~m}$ or more than or equal to $8 \mathrm{~m}$, the roadway will be prevented from the increasing zone of principal stress difference. However, when the coal pillar width is less than or equal to $2 \mathrm{~m}$, it is too small to well isolate the goaf. Therefore, only when the coal pillar width is greater than or equal to $8 \mathrm{~m}$ that the surrounding rock of gob-side entry can be ensured to have good stress environment.

For the stability of surrounding rock of gob-side entry, the stability of roof and coal pillar rib is of great importance. Therefore, the reasonable coal pillar width should guarantee the good stability of surrounding rock on the roof and coal pillar rib. According to the distribution characteristics of principal stress difference of surrounding rock of gob-side entry under different coal pillar widths, the width of the coal pillar has different degrees of impact on the stability of the roof and floor of surrounding rock.

(1) For the roof, when the coal pillar width is greater than or equal to $8 \mathrm{~m}$, the peak value of the peak principal stress difference on the roof is basically stabilized at a low level, which indicates the low stress concentration degree of the roof and the good stress environment of surrounding rock. When the coal pillar width is greater than or equal to $7 \mathrm{~m}$, the position of the peak principal stress difference on the roof is the smallest, indicating the smallest failure depth of the roof, which is conducive to roof support. Therefore, the roof has the best stability when the coal pillar width is greater than or equal to $8 \mathrm{~m}$.

(2) For the coal pillar rib, to maintain the stability of the coal pillar, a stable bearing zone with high stress level possible exists in it. When the coal pillar width is greater than or equal to $6 \mathrm{~m}$, the peak principal stress difference on the coal pillar rib is higher than the original principal stress difference. Hence, the coal pillar has not completely entered the plastic failure state, the stable bearing area exists in the pillar, and the peak principal stress difference is the largest when the coal pillar width is $8 \mathrm{~m}$. However, when the coal pillar width is less than or equal to $6 \mathrm{~m}$, the position of the peak principal stress difference is located at the center of the coal pillar. When the coal pillar width is 7 to $8 \mathrm{~m}$, it deviates towards the roadway, which indicates that the plastic failure depth of coal pillar rib is the smallest, and the stable bearing zone in the pillar is large in this situation. Therefore, the impact on the stability of the coal pillar rib is the smallest when the coal pillar width is $8 \mathrm{~m}$.

(3) For the floor, when the coal pillar width is less than $8 \mathrm{~m}$, the position of the peak principal stress difference on the floor is the same, which indicates that the plastic failure depth of the floor remains unchanged. The position of the peak principal stress difference on the coal wall rib is not affected by the change in the coal pillar width. The plastic failure depth remains unchanged. Therefore, the floor and the coal wall rib have reasonable stability when the coal pillar width is $8 \mathrm{~m}$.

The influence on the stability of surrounding rock of gob-side entry is the smallest when the coal pillar width is $8 \mathrm{~m}$. Based on the theoretical calculation results, the reasonable coal pillar width of gob-side entry should be 8 $\mathrm{m}$.

\subsection{Field Validation}

The field industrial test was carried out in 11030 transport roadway to verify the rationality of the $8 \mathrm{~m}$ long coal pillar of gob-side entry in 11030 transport tunnel in Section 4.3. The field monitoring method described in Section 3.3 was used to monitor the surface displacement of surrounding rock. The roadway in the test section of the 11030 transport roadway was driven along the coal seam roof. Coal pillars $(8 \mathrm{~m})$ were arranged between it and the goaf of 11011 face on the southwest side that had been mined. The support method was designed as the combined support of cable anchor + steel ladder $+\mathrm{W}$-shaped steel belt +16 \# steel channel beam. The specific support parameters were: specification of the bolt: $\varnothing 20 \times \mathrm{L} 2400 \mathrm{~mm}$, array pitch between roof supports: $800 \times 900 \mathrm{~mm}$, array pitch of the rib support: $900 \times 900 \mathrm{~mm}$; specification of anchor: $\varnothing 21.6 \times \mathrm{L} 8250 \mathrm{~mm}$, yow and line space: $1300 \times 900 \mathrm{~mm}$; specification of $16 \#$ channel steel: $12 \times 120 \times 120 \mathrm{~mm}$, specification of steel strip $12 \times 80 \times 80 \mathrm{~mm}$. The support section is shown in Fig. 9.

Fig. 10 presents the monitoring curve of a surface displacement monitoring station obtained by the research method described in Section 3.3. After arranging $8 \mathrm{~m}$ wide coal pillars, no obvious large deformation is formed to the surrounding rock during the roadway driving. In the initial stage of roadway driving, the deformation speed of surrounding rock is high. With increasing time, the deformation speed of surrounding rock decreases gradually. After 40 days of roadway driving, the deformation of surrounding rock no longer increases significantly but remains unchanged. This finding indicates that the surrounding rock of roadway tends to be stable. After the completion of the gob-side entry, the maintenance and use of the roadway are in good condition within the service life (Fig. 11) without roof fall accident. 


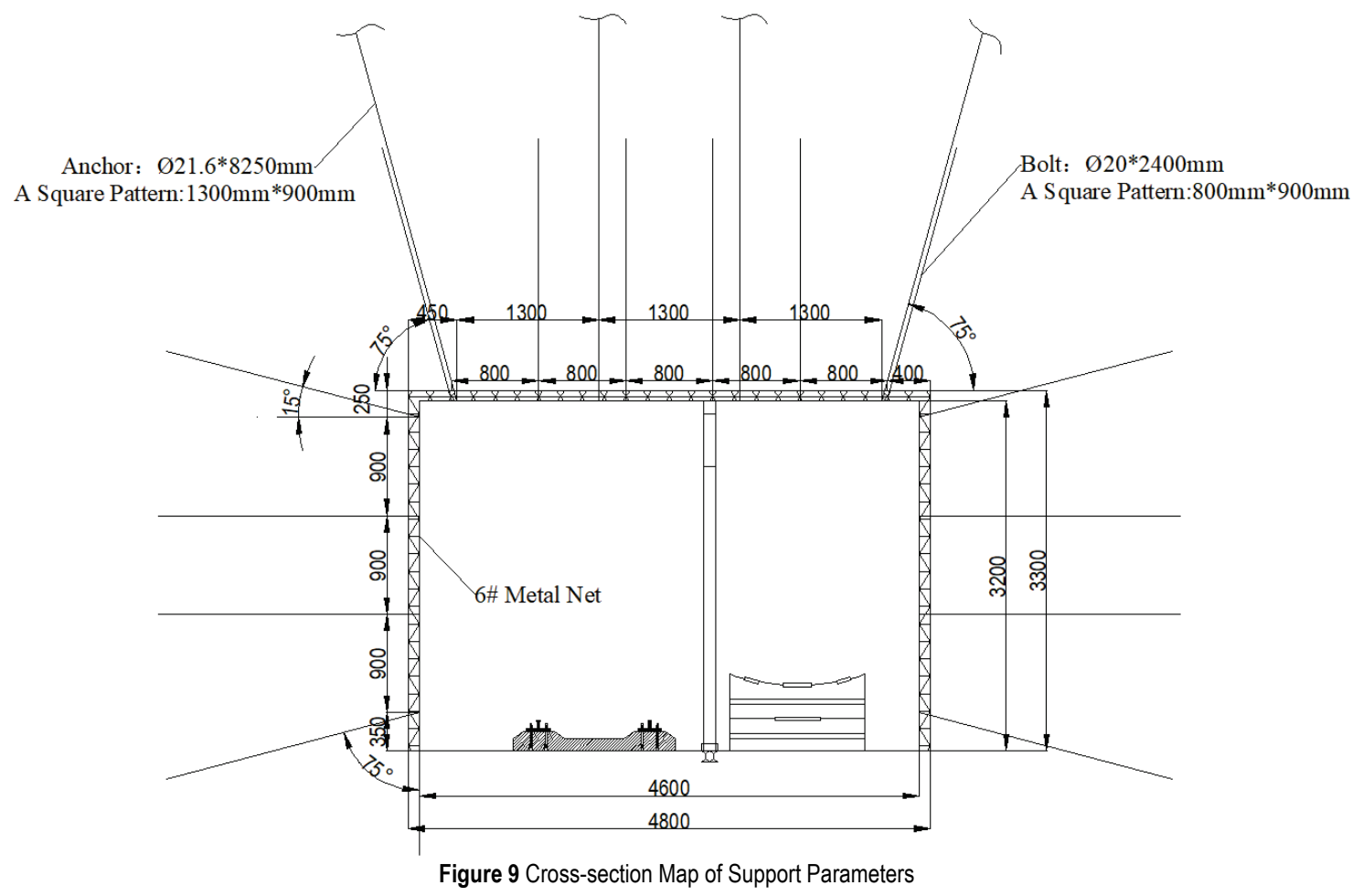

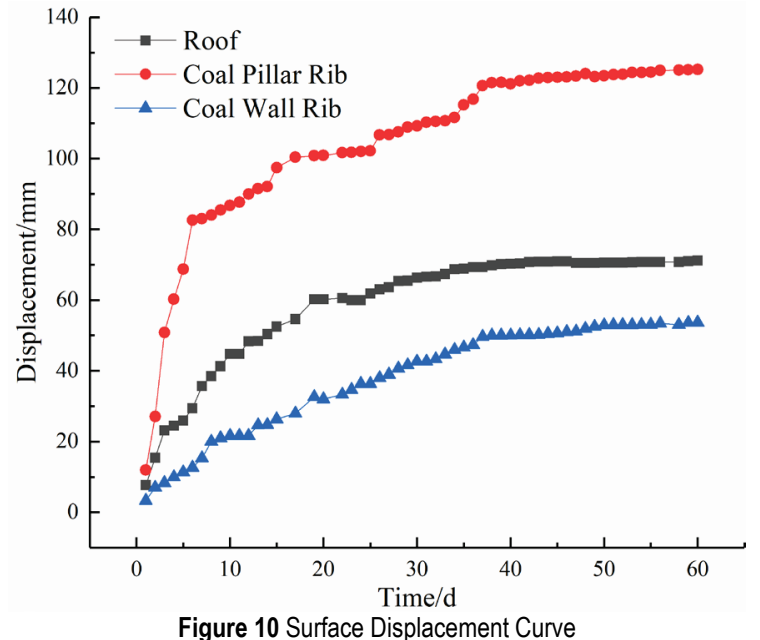

Figure 10 Surface Displacement Curve

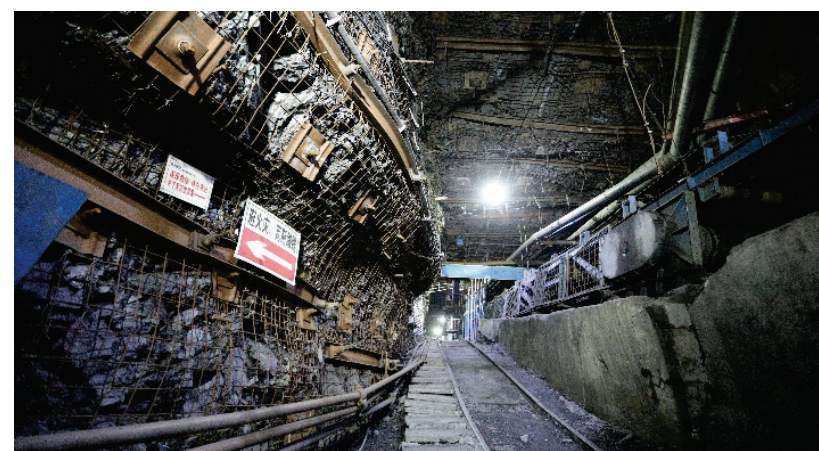

Figure 11 On-site Construction Picture of the Transport Roadway

\section{CONCLUSIONS}

FLAC3D numerical simulation was used to analyze the distribution characteristics of principal stress difference in the side mining stress field of the deep mining face and the distribution law of principal stress difference of surrounding rock of gob-side entry under different coal pillar widths. The deep coal pillar width of gob-side entry was optimized and verified on site based on the theoretical calculation and field monitoring. Finally, the following conclusions were drawn.

(1) The coal and rock mass on the side of goaf can be divided according to the distribution characteristics of the principal stress differences into three zones, namely, decreasing, increasing, and stable zones.

(2) The distribution laws of principal stress differences of surrounding rock on the deep roof, floor and the coal wall rib of gob-side entry are basically the same: that is, it increases rapidly from shallow surrounding rock to the peak and then decreases slowly. The principal stress differences show a single-peak distribution curve.

(3) The principal stress difference of the deep surrounding rock on the coal pillar rib of gob-side entry shows a single-peak distribution curve when the coal pillar width is less than or equal to $8 \mathrm{~m}$. A double-peak curve is obtained when the coal pillar width is greater than $8 \mathrm{~m}$. The peak value of the shallow surrounding rock is obviously smaller than that of the deep surrounding rock.

(4) The reasonable coal pillar width of gob-side entry in the 11030 transport tunnel is greater than or equal to 6 $\mathrm{m}$ based on limit equilibrium theory. According to the distribution law of principal stress difference of surrounding rock of gob-side entry under different coal pillar widths, the influence on the stability of surrounding rock of gob-side entry is the smallest when the coal pillar width is $8 \mathrm{~m}$. Thus, the optimal coal pillar width of gobside entry in the 11030 transport tunnel is $8 \mathrm{~m}$.

Given the close relationship between the principal stress difference of deep coal and rock mass and the shear failure of surrounding rock, the distribution characteristics of principal stress difference in the side mining stress field of deep mining face and the distribution law of principal stress difference of surrounding rock of gob-side entry under different coal pillar widths were obtained. This paper can provide a foundation for $t$ scientific and reasonable optimum design of deep coal pillar width of gob-side entry. 
However, the distribution law of principal stress difference obtained is mainly based on the actual production geological conditions of Zhaogu No. 2 Mine. The result provides a reference for the optimum design of deep coal pillar width of gob-side entry under similar geological conditions. The applicability to other production geological conditions needs further study because of the changing production geological conditions of coal mining.

\section{Acknowledgements}

This study was supported by the National Natural Science Foundation of China (No. 51804243), the Natural Science Basic Research Plan of Shaanxi Province of China (No. 2018JQ5200).

\section{REFERENCES}

[1] Kacprzak, A., Kobyłecki, R., \& Bis, Z. (2017). The effect of coal thermal pretreatment on the electrochemical performance of molten hydroxide direct carbon fuel cell (MH-DCFC). Journal of Power Technologies, 97(5), 382387.

[2] Xie, H. P., Gao, F., \& Ju, Y. (2015). Research and development of rock mechanics in deep ground engineering. Chinese Journal of Rock Mechanics and Engineering, 34(11), 2161-2178. https://doi.org/10.13722/j.cnki.jrme.2015.1369

[3] Peng Kang, Liu Zhaopeng, Zou Quanle, Zhang Zhenyu, \& Zhou Jiaqi (2019). Static and dynamic mechanical properties of granite from various burial depths. Rock Mechanics and Rock Engineering, (4), 1-22 https://doi.org/10.1007/s00603-019-01810-y

[4] Agapito, J. F. T., Maleki, H. N., \& Moon, M. (1988). Twoentry longwall gate road experience in a burst-prone mine. In: Proceeding of AMC international MINEXPO, vol II. American mining congress, Chicago, IL, 271-292.

[5] Xie, G. X., Yang, K. \& Liu, Q. M., (2006). Study on distribution laws of stress in inclined coal pillar for fullymechanized top-coal caving face. Chinese Journal of Rock Mechanics and Engineering, 25(3), 545- 548. https://doi.org/10.3321/j.issn:1000-6915.2006.03.017

[6] Zhang, K. Z., Xia, J. M., \& Jiang, J. Q., (2004). Variation law of quantity of coal dust in drill hole and its application to determination of reasonable width of coal pillars. Chinese Journal of Rock Mechanics and Engineering, 43(8), 13071310. https://doi.org/10.3321/j.issn:1000-6915.2004.08.014

[7] Quansen Wu, Lishuai Jiang, Quanlin Wu, Yanchao Xue, \& Bin Gong (2018). A study on the law of overlying strata migration and separation space evolution under hard and thick strata in underground coal mining by similar simulation. DYNA, 93(2), 175-181. https://doi.org/10.6036/8678

[8] Perry, K. A., Unrug, K. F., Harris, K. W., \& Raffaldi, M. J. (2013). Influence of Roof/Floor Interface on Coal Pillar Performance. Paper presented at the 32nd International Conference on Ground Control in Mining, Morgantown, WV Retrieved from https://www.researchgate.net/ publication/328942817_Influence_of_RoofFloor_Interface on_Coal_Pillar_Performance

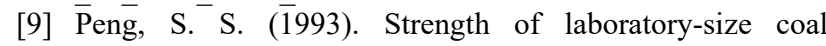
specimens vs. underground coal pillars. Mining Engineering, (3), 162-165.

[10] Bai, J. B. \& Hou, C. J. (2004). Numerical simulation study on stability of narrow coal pillar of roadway driving along goaf. Chinese Journal of Rock Mechanics and Engineering, 23(20), 3475-3479. https://doi.org/10.3321/j.issn:1000-6915.2004.20.015

[11] Chang, J. C., Xie, G. X., \& Yang, K. (2008). Determination of reasonable width for small coal pillar with gob-side entry driving in fully mechanized top-coal caving face. Journal of Xi'an University of Science and Technology, 28(2), 226- 230. https://doi.org/10.3969/j.issn.1672-9315.2008.02.006

[12] Jia, G. S. \& Kang, L. J. (2002). Study on the chain pillar stability of the developing entry in longwall top-coal mining. Journal of China Coal Society, 27(1), 6-10. https://doi.org/10.3321/j.issn:0253-9993.2002.01.002

[13] Yin, Q., Jing, H., \& Dai, D. (2016). Cable-truss supporting system for gob-side entry driving in deep mine and its application. International Journal of Mining Science and Technology, 26(5), 885-893. https://doi.org/10.1016/j.jjmst.2016.05.038

[14] Wang, M., Bai, J. B., \& Li, W. F. (2015). Failure mechanism and control of deep gob-side entry. Arabian Journal of Geosciences, 8(11), 9117-9131. https://doi.org/10.1007/s12517-015-1904-6

[15] Bertuzzi, R., Douglas, K., \& Mostyn, G. (2016). An Approach to model the strength of coal pillars. International Journal of Rock Mechanics and Mining Sciences, 89, 165175. https://10.1016/j.jijmms.2016.09.003

[16] Jiang, L., Zhang, P., \& Chen, L. (2017). Numerical Approach for Goaf-Side Entry Layout and Yield Pillar Design in Fractured Ground Conditions. Rock Mechanics and Rock Engineering, 50(11), 3049-3071. https://doi.org/10.1007/s00603-017-1277-0

[17] Ming, Z., Shuai, Z., \& Yong, C. (2015, Mar). Reasonable Width of Narrow Coal Pillar of Gob-side Entry Driving in Large Mining Height. Paper presented at the 2nd International Conference on Advances in Energy Resources and Environment Engineering, Daqing, Heilongjiang Province, China. Retrieved from https://iopscience.iop.org/ article/10.1088/1755-1315/59/1/012025/pdf

[18] Seryakov, V. M., Rib, S. V., \& Fryanov, V. N. (2017). Stress State of a Coal Pillar in Fully Mechanized Longwall Mining in Dislocation Zone. Journal of Mining Science, 53(6), 10011008. https://doi.org/10.1134/S1062739117063065

[19] Zhang, Y., Wan, Z. J., \& Li, F. C. (2013). Stability of coal pillar in gob-side entry driving under unstable overlying strata and its coupling support control technique. International Journal of Mining Science and Technology, 23(2), 193-199. https://doi.org/10.1016/j.jmst.2013.04.020

[20] Mall, T., Yetkin, M. E., Özfirat, M. K., \& Kahraman, B. (2017). Numerical analysis of underground space and pillar design in metalliferous mine. Journal of African Earth Sciences, 134, 365-372. https://doi.org/10.1016/j.jafrearsci.2017.07.018

[21] Zhang, W., Zhang, D. S., \& Chen J. B. (2014). Control of surrounding rock deformation for gob-side entry driving in narrow coal pillar of island coalface. Journal of China University of Mining \& Technology, 43(1), 36-42. https://doi.org/10.13247/j.cnki.jcumt.000013

[22] Zhang, X. G., Yao, Z. G., \& Zhang, N. (2012). Stress distribution of coal pillar with gob-side entry driving in the process of excavation \& mining. Journal of Mining \& Safety Engineering, 29(4), 459-465.

[23] Mehdi Najafi, Amirhossein Shishebori \& Javad Gholamnejad (2017). Numerical Estimation of Suitable Distance between Two Adjacent Panels' Working Faces in Shortwall Mining. International Journal of Geomechanics, 17(4), 040160901-0401609011. https://doi.org/10.1061/(ASCE)GM.1943-5622.0000784

[24] Kumara, A., Waclawik, P., Singha, R., et al. (2017). Performance of a coal pillar at deeper cover: Field and simulation studies. International Journal of Rock Mechanics and Mining Sciences, 113(1), 322-332. https://doi.org/10.1016/j.jijmms.2018.10.006 
[25] Rezaei, M. (2018). Forecasting the stress concentration coefficient around the mined panel using soft computing methodology. Engineering with Computers, (1), 1-16. https://doi.org/10.1007/s00366-018-0608-4

[26] Li Chuan-ming, Shi Wen-bao, Liu Wan-rong \& Feng Ruimin. (2017). Elastic-Plastic Analysis of Surrounding Rock in Deep Roadway Considering Shear Dilatancy Property under Non-Uniform Stress Field. Journal of Engineering Science and Technology Review, 10(4), 16-24 https://doi.org/10.25103/jestr.104.03

[27] Xie, S. R., Li, S. J., \& Huang, X. (2015). Surrounding rock principal stress difference evolution law and control of godside entry driving in deep min. Journal of China Coal Society, 40(10), 2355-2360. https://doi.org /10.13225/j.cnki.jccs.2015.6002

[28] He, F. L., Wang, X. M., \& Xu, L. (2014). Principal stress difference transfer law and support in large-section open-off cut. Rock and Soil Mechanics, 35(6), 1703-1710. https://doi.org /10.16285/j.rsm.2014.06.022

[29] Hou, C. J. \& Ma, N. J. (1989). Stress in in-seam roadway sides and limit equilibrium zone. Journal of China Coal Society, (4), 21-29. https://doi.org/10.13225/j.cnki.jccs.1989.04.003

[30] Bai, J. B., Wang, W. J., \& Hou, C. J. (2000). Control mechanism and support technique about gateway driven along goaf in fully mechanized top coal caving face. Journal of China Coal Society, 25(5), 478-481. https://doi.org/10.13225/j.cnki.jccs.2000.05.007

\section{Contact information:}

Ji LI, Assistant Professor, PhD

(Corresponding author)

1) School of Energy, X'ian University of Science and Technology,

Xi'an, 58 Yanta Middle Road, Xi'an 710054, Shaanxi Province, China

2) Key Laboratory of Western Mine and Hazard Prevention,

Ministry of Education, Xi'an, Shaanxi, China

E-mail: liji@xust.edu.cn

\section{Xubo QIANG}

School of Energy, Xi'an University of Science and Technology, 58 Yanta Middle Road, X''an 710054, Shaanxi Province, China E-mail: 1403763782@qq.com

\section{Wenshuo WANG}

School of Energy, Xi'an University of Science and Technology, 58 Yanta Middle Road, Xi'an 710054, Shaanxi Province, China E-mail:wangwenshuoi@163.com

Fei WANG, PhD

Department of Mining Engineering, Colorado School of Mines,

Golden, CO 80401, USA

E-mail: fwangmines@hotmail.com 